\title{
The Relationship among Website Quality, Consumer Satisfaction, and Loyalty in Vietnamese Banking Sector
}

\author{
LE VAN HUY \\ The University of Danang, University of Economics - levanhuy@due.edu.vn \\ PHAM DINH TUYEN \\ The University of Danang, University of Economics - tuyenpham0208@gmail.com
}

\begin{abstract}
ARTICLE INFO ABSTRACT
Article history:

Received:

Oct. 13. 2014

Received in revised form:

May 21. 2015

Accepted:

Jun. 28. 2015

Keywords:

website quality, satisfaction, loyalty,

Recently, together with the development of information technology, banks have found and put into use more and more channels to deal with their customers, and one of them is the provision of websites to satisfy customers' need. That is the reason why customer satisfaction in e-banking services is an important challenge to all banks. This study aims to identify the effects of website quality on customer satisfaction, which in turn affects their loyalty toward the banks. For this purpose website quality dimensions, including information quality, navigation, response time, visual appeal, interactivity, security, and innovativeness, are tested by applying regression to the analyses. Additionally, all the data for this research, collected from banking customers through the questionnaires, allow such dimensions as information quality, interactivity, security, and innovativeness to be explored as having contributed significantly to customer satisfaction, which leads to their loyalty to the banks.
\end{abstract} interactivity, innovativeness. 


\section{Introduction}

Success of a service provider depends on the high quality relationship with customers (Panda, 2003), which determines customer satisfaction and loyalty (Jones, 2002 as cited by Lymperopoulos et al., 2006). In recent years the popularity of the Internet has not only encouraged the development of new industry sectors but also changed the business model of many others, especially for banks (Barwise \& Farley, 2005). That is the way banks deal with and serve their customers online. In the current fiercely competitive market the challenging business environment has resulted in an increase in pressure on commercial banks to develop and make full use of alternative delivery channels, with the aim to attract more customers, to improve customers' perceptions, and to encourage loyalty (Jalvagi \& Moberg, 1997). According to a study conducted by Nua Internet Surveys. (2002), more than 553 million people worldwide have access to the Internet till then. The considerably global penetration of the Internet has led to significant improvements as customers and enterprises conduct their business transactions via the Web. Thus, banks' website is one of the most useful delivery channels recently introduced, and banks serve customers through the websites by allowing them to access accounts, search for useful information, and perform financial transactions online (Haque et al., 2009).

Besides, e-transaction system offers banks and their customers many outstanding features such as better accessibility, more convenience, and lower costs, compared to other traditional channels (Brynjolfsson \& Smith, 2000). Particularly, Vietnam banking system, for the last few years, has experienced a significant switch to such another delivery channel of banking services as the websites. That is the reason why banks' managers should identify and understand how website quality can influence customer satisfaction in order to retain and better serve their customers.

Moreover, today's advances in information and communication technology have made online banking services accessible elsewhere throughout the countries. Therefore, there is a special need to understand banking sector websites through examining factors that influence user's intention to use, return to, and recommend the websites to others. This may open the gate for strategic planning and decision-making processes in commercial banks as these wish to introduce or develop online banking services to customers in different contexts. This study is thus conducted to identify the 
quality effects on customer satisfaction, which in turn affects their loyalty toward the banks.

\section{Literature review and research model}

It has been concluded in many studies that website service quality is crucial to promote customers' perceived satisfaction with a bank's website (Kim \& Lee, 2004; Madu \& Madu, 2002). Meanwhile, satisfaction plays an important part in establishing long-term relationships with customers and generating further loyalty.

Satisfaction refers to consumers' evaluation of how much their needs are fulfilled, and it is the most relevant variable in the study of customer loyalty (Castaneda et al., 2009). Furthermore, many researchers have found that the overall satisfaction experienced by online customers reduces the perceived benefits of alternative service providers, which in turn yields stronger repurchase intentions for online services (Szymanski \& Hise, 2000). According to Patterson et al. (1997), customer satisfaction is significant for long-term relationships, which is signified by the variable of customer loyalty. Meanwhile, Oliver (1999) claimed that customer loyalty not merely is a strong asset for the firms but also aims the firm toward sustainable growth and profit.

The theoretical model guiding the investigation is based on WEBQUAL model (Cao et al., 2005) and Bagozzi's (1992) self-regulation processes. This study, in an effort to evaluate the influence of website quality on customer satisfaction and loyalty toward the online banking service, identifies seven factors of website quality, among which five are adapted from a study by Gao (2013), including information quality, navigation, response time, visual appeal, and interactivity, and the other two consist of security and innovativeness based on Loiacono et al. (2002). Our model suggests that consumers' coping response is influenced by website quality indirectly through esatisfaction.

\section{Information quality}

Information quality refers to the accuracy and the form of information about the products and services offered on a website. Customers visit a website for a wide range of reasons, one of which is to look for useful information about price, product types, and promotional campaigns. Therefore, providing dated and accurate information is the basic goal of a website (Kim \& Lee, 2004). According to Cai et al. (2004), the detailed and diverse information is a main driver for customers to choose to go online because 
it customizes their transaction to serve them better (Kim et al., 2006). Peterson et al. (1997) clarified that superior information quality offered online results in better purchasing decisions and higher satisfaction, which influences customer relationship with the service providers. Barnes and Vidgen (2002) and Loiacono et al. (2007) believed that website information quality is crucial to the success of a website, and it is also one of the most important drivers for customers to interact with the website.

H1: Information quality of banking sector websites will have a positive impact on consumer satisfaction.

\section{Navigation}

Website navigation influences users' fluency of visiting a website for transaction experiences and their attitudes toward the website (Eagly and Chaiken, 1993). Limayem et al. (2003) found that a good navigation system makes it easier for customers to approach infinite and updated information. It also imposes positive influence on online customers' purchasing intentions (Verhagen \& van Dolen, 2009) because e-customers may figure out or may be unwilling to return to the website if the online transaction system lacks sufficient navigation tools (Kim et al., 2003). It is a matter of fact that once consumers perceive a website to be too time-consuming to navigate to where they want, they may detect it and decide not to return (Luo \& Seyedian, 2004). To this concern, Clyde (2000) proposed a search engine on websites, which may enable customers to look around them easily. The advantages of a huge number of navigation tools to a site are plentiful, ranging from the more traffic that customers can expect to receive, to the higher ranking of the site as a result of many available search engines (Miranda and Bañegil, 2004).

H2: Navigation of banking sector websites will have a positive impact on consumer satisfaction.

\section{Response time}

Fast loading speed of a website plays an important role in customer satisfaction (Chen \& Dibb, 2010). Many studies have proven the significant correlation between website download speed and web-user satisfaction, which helps build intimate customer relationship with the service providers (Hoffman \& Novak, 1996). Among these Kim and Stoel (2004) firmly believed that fast response time exercises significantly positive influence on consumer satisfaction with online shopping. Moreover, in terms of waiting time on the Internet, Weinberg (2000) clearly pointed 
out that once the homepage loads fast enough, the efforts toward acquiring customer satisfaction will be rewarded. Fast response time in searching for service information as well as making transactions could satisfy customers' web-based transaction experience by fluent and time-saving services.

H3: Response time of banking sector websites will have a positive impact on consumer satisfaction.

\section{Visual appeal}

Loiacono et al. (2007) referred to visual appeal as one of the key factors to evaluate website quality. According to Simon (2001), the feature of visual appeal is an elaborate combination of color, shape, and layout as well as the arrangement of information on the websites. With regard to website visual appeal, Smith and Merchant (2001) claimed that whether the information is accurately provided or how easy it is to navigate around the site is not as important as the website appealing and that once customers do not find the site appealing enough, they will not spend much time there. To the same extent Syahrul and Sidi (2005) acknowledged that an attractive website is the one that encourages more online consumers to search the website. In contrast, poor website design leads to the loss of potential customers due to the impossibility for them to find what they want and the loss of potential repeated visits due to a repetitively negative transaction experience (Miranda et al., 2006). Furthermore, Cyr et al. (2010) certified emotional components in website design as significant to users' attitudes toward the websites.

H4: Visual appeal of banking sector websites will have a positive impact on consumer satisfaction.

\section{Interactivity}

An important website element of interaction system includes the combination of website response and website customization ability. Website customization is regarded as the extent to which a website can identify customers, their profiles, and their needs, and then adjust their choice of products and services from a website (Srinivasan et al., 2002). While online services can be defined as the interaction between consumers and websites (Bitner, 1990), Zhao and Dholakia (2009) insisted that website interactivity has multiple features, such as keyword search, personalization, and customer feedback. These interactivity functions could enable customers' transactional behavior via the website, and it could positively influence consumer satisfaction (Rafaeli, 1988). 
H5: Interactivity of banking sector websites will have a positive impact on consumer satisfaction.

\section{Security}

A website stores and manages a wide variety of personal information about its customers in order to serve them better. Thus, its privacy and security features have become a great concern to customers during their online transactions and contributed to customer satisfaction. Madu and Madu (2002) also suggested that online services should be delivered and operated in a reliable and dependable manner to build trust and confidence from customers. Since customers purchase products online without physical exchange of credit card or cash, it is critical to ensure the safety of transactions on a website (Ho \& Lee, 2007). According to Kim \& Lee (2004), privacy/security involves transactional functions, which enable customers to perceive the website as intuitive, simple, and user-friendly for completing transactions. Hence, when the perceived level of security satisfies customers' expectations, they may be willing to disclose personal information with an increased level of trust (Park \& Kim, 2003; McKnight \& Chervany, 2002).

H6: Security of banking sector websites will have a positive impact on consumer satisfaction.

\section{Innovativeness}

The popularity of the Internet and new technologies has had websites' new features constantly updated to satisfy customers' need. A study by Ouellet (2008) considered another dimension of innovativeness, namely the frequency of website innovativeness referred to as "updating." Besides, Loiacono et al. (2007) identified the innovativeness of websites as a construct of website quality measurement in marketing researches, defining innovativeness of a website as "the creativity and uniqueness of a website." The higher the creativity and uniqueness of a website, the greater the competitive advantages are sets on its counterpart, and thus the higher the possibility that customers will be satisfied with, return to, and regularly use that website. Additionally, more innovativeness of a website also means that new technologies and new products will be constantly updated as well as introduced to customers, who themselves in turn feel curious about what is new on today's websites, and this leads to their regular access to the website to search for necessary information and benefit from the service quality it offers. 
H7: Innovativeness of banking sector websites will have a positive impact on consumer satisfaction.

\section{Satisfaction and loyalty}

According to Kim \& Niehm (2003), customer loyalty not merely is a strong asset for the firms, but also aims them toward sustainable growth and profit. Besides, Anderson and Mittal (2000) found that in defining the development of loyalty, satisfaction has been considered as the critical concept in the previous marketing literature. Perceived website quality is also the attitude toward the superiority of a website, whereas satisfaction is associated with a specific transaction (Parasuraman et al., 1988). Similarly, customer satisfaction has been appreciated as the major determinant of loyalty (Lam \& Burton, 2006). As supported by Ehigie (2006), a significant positive relationship is held between customer satisfaction and customer loyalty. Customer satisfaction in this study, therefore, should be acting as a mediator between service quality and customer loyalty.

H8: Consumer satisfaction will have a positive influence on their loyalty.

Appraisal Process

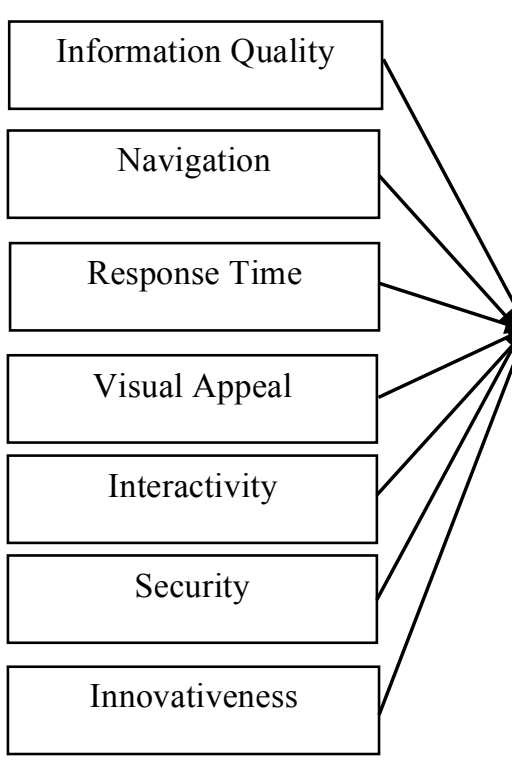

Emotional Reaction

Coping Response
Customer's Satisfaction

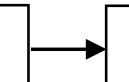

Fig. 1. Research model 


\section{Methodology}

\subsection{Sample and data collection method}

The target population of the study are those who have online transactional behavior via the websites of banks in the Vietnamese banking system, especially the young customers. Data collection was conducted through questionnaires delivered to customers via the Internet, to be more specific, the Facebook and Gmail. Among 600 sets of questionnaires which were distributed to the potential respondents, a total of 489 questionnaires were collected. Out of these 80 sets of questionnaires were invalid because respondents neither had experience with banking services nor completed the questionnaires. Therefore, only 409 usable sets of collected questionnaires were valid for further analyses.

The constructs of website quality, customer satisfaction, and customer loyalty suggested for evaluation involved an average of three items considered. All the items were evaluated based on a five-point Likert scale with the value of 1 representing "strongly disagree" and 5 representing "strongly agree." The extent of customers" agreement with the statement increases from 1 to 5 .

\subsection{Research design}

This research employs both qualitative and quantitative methods. While the qualitative method involves the process of collecting, identifying, evaluating, and systematizing the theoretical review by previous researchers through the newspaper, magazine, and the Internet, the quantitative method is adopted via the process of collecting data through questionnaires and applying SPSS software to analyze the results by the techniques of descriptive statistics, EFA, Cronbach's alpha, and regression analysis.

\section{Data analysis}

4.1. Customers' demographic information and online banking transactional behavior

SPSS 16.0 statistical software has allowed for descriptive statistics of the sample. For the sample size of $n=409$ male respondents account for $43.3 \%$, whereas this figure for female is $56.7 \%$. Besides, a majority of respondents in this research are within the 
age of 18-30 years old (59.9\%). The age groups of 30-42 and over 42 years old make up $31.1 \%$ and $6.8 \%$ respectively.

\section{Table 1}

Statistics of demographic information

\begin{tabular}{lcc}
\hline Characteristic & Frequency & Percentage \\
\hline Gender & $\mathrm{N}=409$ & \\
Male & 177 & 43.3 \\
Female & 232 & 56.7 \\
Age & $\mathrm{N}=409$ & \\
$0-<18$ years old & 9 & 2.2 \\
$18-<30$ years old & 245 & 59.9 \\
$30-<42$ years old & 127 & 31.1 \\
$>=42$ years old & 28 & 6.8 \\
\hline
\end{tabular}

Besides, customers' online banking transactional behavior is signified by their frequency of accessing banking websites. The statistics shows that the sample covers relatively high exposure to banking websites as most people have used these websites for at least once a month. Specifically, the proportions of respondents accessing banking websites with the frequencies of 1-2 times and 3-4 times a month reach $30.3 \%$ and $49.4 \%$ respectively. The demographic profile of the respondents showed in Table 1 represents a diverse section of the population.

\section{Table 2}

Statistics of customers' online transactional frequencies

\begin{tabular}{llccc}
\hline & Frequency & Valid Percent & Cumulative Percent \\
\hline Valid & Never & 1 & 0.2 & 0.2 \\
& $1-2$ times & 124 & 30.3 & 30.6 \\
& 3-4 times & 202 & 49.4 & 80.0 \\
& $5-6$ times & 71 & 17.4 & 97.3 \\
7-8 times & 11 & 2.7 & 100.0 \\
& More than 8 times & 409 & 100.0 & \\
\hline
\end{tabular}




\subsection{Exploratory factor analysis and Cronbach's alpha analysis}

Exploratory factor analysis (EFA) is conducted on each construct of website quality, customer satisfaction, and customer loyalty. For website quality signified by the six constructs, the EFA results come up with the value of $\mathrm{KMO}=0.837$ and $\mathrm{sig}=0.000<0.05$, which proves that the data were valid for factor analysis.

Out of the original 24 items those considered unsatisfactory are removed (due to their factor loading being less than 0.3 or their cross loading). The result by the total variance explained shows that there are six factors to be extracted, all of which make up $68.38 \%(>50 \%)$ of the total variance. Besides, the result obtained by the reliability analysis also verifies that Cronbach's alpha values range between 0.6 and 0.9 , and such indicates high internal consistency for all of the six extracted factors.

The EFA results also enable the adjustment of the theoretical model. To that extend this research aims to evaluate the relationship between the six components of website quality (labelled response time, information quality, security, interactivity, visual appeal, and innovativeness) and customer satisfaction as well as the linkage between customer satisfaction and customer loyalty.

\section{Table 3}

EFA results

\begin{tabular}{|c|c|c|c|c|c|c|c|}
\hline & & & & & ent & & \\
\hline & & 1 & 2 & 3 & 4 & 5 & 6 \\
\hline $\mathrm{rt1}$ & $\begin{array}{l}\text { The website responses quickly to } \\
\text { customer's request. }\end{array}$ & .816 & & & & & \\
\hline $\mathrm{rt} 3$ & The website loads without any delay. & .727 & & & & & \\
\hline $\mathrm{rt} 2$ & $\begin{array}{l}\text { The website is always ready for } \\
\text { customers to conduct transactions. }\end{array}$ & .707 & & & & & \\
\hline $\mathrm{rt} 4$ & $\begin{array}{l}\text { The speed of accessing the website is } \\
\text { satisfactory. }\end{array}$ & .580 & & & & & \\
\hline wiq1 & $\begin{array}{l}\text { The website provides relevant } \\
\text { information. }\end{array}$ & & .816 & & & & \\
\hline wiq2 & $\begin{array}{l}\text { The information presented is accurate } \\
\text { and valid. }\end{array}$ & & .787 & & & & \\
\hline
\end{tabular}




\begin{tabular}{|c|c|c|c|c|c|c|c|}
\hline & \multirow{2}{*}{ Item } & \multicolumn{6}{|c|}{ Component } \\
\hline & & 1 & 2 & 3 & 4 & 5 & 6 \\
\hline wiq3 & $\begin{array}{l}\text { The information presented covers all } \\
\text { information needs. }\end{array}$ & & .735 & & & & \\
\hline sase 1 & $\begin{array}{l}\text { The website completely secures my } \\
\text { transactional information. }\end{array}$ & & & .850 & & & \\
\hline sase2 & $\begin{array}{l}\text { Declarations of security policy by the } \\
\text { website are clear. }\end{array}$ & & & .789 & & & \\
\hline sase3 & $\begin{array}{l}\text { My personal information is not } \\
\text { shared with other websites. }\end{array}$ & & & .696 & & & \\
\hline wint1 & $\begin{array}{l}\text { The website caters for special } \\
\text { requirements. }\end{array}$ & & & & .842 & & \\
\hline wint3 & $\begin{array}{l}\text { It is easy to communicate with banks } \\
\text { via the website. }\end{array}$ & & & & .767 & & \\
\hline wint2 & $\begin{array}{l}\text { The website allows for extended } \\
\text { search. }\end{array}$ & & & & .711 & & \\
\hline va1 & $\begin{array}{l}\text { The content is well-organized and } \\
\text { readable. }\end{array}$ & & & & & .842 & \\
\hline va3 & The website design looks attractive. & & & & & .791 & \\
\hline va2 & $\begin{array}{l}\text { The website design (e.g. color } \\
\text { combinations, text size, etc.) is } \\
\text { aesthetically appropriate. }\end{array}$ & & & & & .731 & \\
\hline win3 & $\begin{array}{l}\text { The website is a great improvement } \\
\text { compared to others. }\end{array}$ & & & & & & .798 \\
\hline win2 & $\begin{array}{l}\text { The website is updated with modern } \\
\text { features. }\end{array}$ & & & & & & .796 \\
\hline win 1 & $\begin{array}{l}\text { The website provides innovative } \\
\text { products. }\end{array}$ & & & & & & .723 \\
\hline
\end{tabular}




\begin{tabular}{|c|c|c|c|c|c|c|}
\hline \multirow{2}{*}{ Item } & \multicolumn{6}{|c|}{ Component } \\
\hline & 1 & 2 & 3 & 4 & 5 & 6 \\
\hline Eigenvalue & 5.900 & 1.819 & 1.568 & 1.360 & 1.289 & 1.029 \\
\hline$\%$ of variance & 12.221 & 11.468 & 11.353 & 11.339 & 11.045 & 10.811 \\
\hline Cumulative \% variance & 12.221 & 23.688 & 35.041 & 46.381 & 57.425 & 68.237 \\
\hline Cronbach's alpha & .756 & .780 & .811 & .790 & .758 & .737 \\
\hline
\end{tabular}

Furthermore, the EFA of the variables representing customer satisfaction and customer loyalty to a banking website enables the extraction of one factor of customer satisfaction from the four original items and one factor of customer loyalty from the three original items. The reliability analysis suggests Cronbach's alpha values of the extracted factors being compellingly within the acceptable interval of 0.6-0.9, which demonstrates the internal consistency of these factors.

\section{Results and discussion}

\subsection{Results}

Regression analysis is used to examine the validation of all hypotheses quoted in the study. The results show that among the six variables suggested for testing in relation to customer satisfaction four hypotheses of the relationship between customer satisfaction and information quality $(\beta=0.108 ; \mathrm{H} 2)$, security $(\beta=0.257 ; \mathrm{H} 3)$, interactivity $(\beta=0.109 ; \mathrm{H} 4)$, and innovativeness $(\beta=0.170 ; \mathrm{H} 6)$ are verified. Moreover, the results of the regression coefficients indicate that there do not exist the situations of multicollinearity and autocorrelation because the value of VIF of all the variables is less than 5 , and Durbin-Watson $=1.612$. Besides, $\mathrm{R}^{2}=62,3 \%$ suggests that the four variables within the website quality constructs explain $62.3 \%$ of the variance in customer satisfaction.

The results also support the hypothesis $\mathrm{H} 7(\mathrm{~F}=236.467$ and sig=0.000), confirming the relationship between customer satisfaction and customer loyalty in banking industry sector, a variable signified by customers' intention of retention and their introducing the website to other potential customers. 


\section{Table 4}

Regression analysis results

\begin{tabular}{llcccc}
\hline Hypothesis & Supported & Coefficient & Std. Error & p-value \\
\hline H1: Response time & $\rightarrow$ Satisfaction & No & 0.080 & 0.042 & 0.058 \\
H2: Information quality & $\rightarrow$ Satisfaction & Yes & 0.108 & 0.040 & $0.007^{* *}$ \\
H3: Security & $\rightarrow$ Satisfaction & Yes & 0.257 & 0.039 & $0.000^{* *}$ \\
H4: Interactivity & $\rightarrow$ Satisfaction & Yes & 0.109 & 0.035 & $0.002^{* *}$ \\
H5: Visual appeal & $\rightarrow$ Satisfaction & No & 0.010 & 0.030 & 0.731 \\
H6: Innovativeness & $\rightarrow$ Satisfaction & Yes & 0.170 & 0.035 & $0.000^{* *}$ \\
H7: Satisfaction & $\rightarrow$ Loyalty & Yes & 0.669 & 0.043 & $0.000^{* *}$ \\
\hline
\end{tabular}

Path significance $* * \mathrm{p}<.01, * \mathrm{p}<.05$

\subsection{Discussion}

Based on the previous theoretical models and studies, an effort is made to evaluate banks' website quality in the Vietnamese banking system in relation to the promotion of customer satisfaction and loyalty toward online banking services. Regression analysis results show that security has the strongest relationship with customer satisfaction in online banking activities. Once the security of a website is sufficient to build customer trust and confidence in making online transactions, their satisfaction would be achieved. This has been supported by the preceding studies of Kim \& Lee (2004), Yang et al. (2005), Yoo \& Donthu (2001), and Liu \& Arnett (2000).

Besides, the feature of innovativeness bears the second strongest relationship with customer satisfaction. Innovativeness attracts customers' attention to banking service websites, which enables customers to instantly update new information, products, or features offered by the websites and supports their transactional behavior. These findings come in line with a study by Loiacono et al. (2002) when pointing out that security positively influences customer satisfaction.

However, response time and visual appeal are not positively related to customer satisfaction with banking activities as pointed out by the results. This does not support the proposal discussed by Kim and Stoel (2004) and Chen and Dibb (2010). Specifically, satisfaction is found to be positively related to customers' intention to 
revisit a website and/or make transactions online, as well as to recommend it to others. This result promotes the study by Kim \& Niehm (2009).

\section{Table 5}

Summary of dimensions measuring website service quality in different studies

\begin{tabular}{|c|c|c|c|c|c|c|c|c|c|c|c|c|c|}
\hline & Concept & 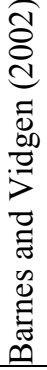 & 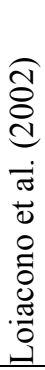 & 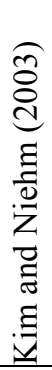 & 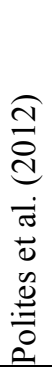 & 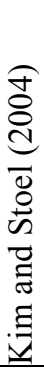 & 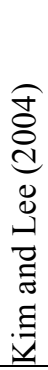 & 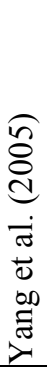 & 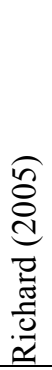 & 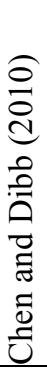 & 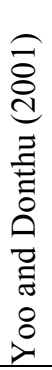 & 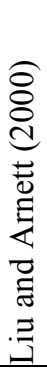 & 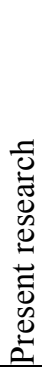 \\
\hline 1 & $\begin{array}{l}\text { Information } \\
\text { quality }\end{array}$ & + & + & + & + & + & + & + & + & & & & + \\
\hline 2 & Navigation & + & + & & & & & & + & & & & \\
\hline 3 & $\begin{array}{l}\text { Response } \\
\text { Time }\end{array}$ & & + & & & + & & & & + & & & \\
\hline 4 & $\begin{array}{l}\text { Visual } \\
\text { appeal }\end{array}$ & + & + & & & + & & & & + & + & + & \\
\hline 5 & Interactivity & + & + & & & & & & & & & & + \\
\hline 6 & Security & & & & & & + & + & & & + & + & + \\
\hline 7 & $\begin{array}{l}\text { Innovativen } \\
\text { ess }\end{array}$ & & + & & & & & & & & & & + \\
\hline 8 & Satisfaction & + & & + & + & & & & & & & & + \\
\hline
\end{tabular}

\section{Conclusion, limitations, and managerial implications}

\subsection{Conclusion and limitations}

Even though this research has contributed significantly to the perception of banking website quality in relation to the promotion of customer satisfaction and loyalty in banking activities, it is not free of limitations due to the fact that many of the respondents could not give objective evaluations on a specific website of the bank with which they had conducted transactions and so these may not be the best representatives 
for the population. Besides, this research focuses mainly on those who have had access to the Internet; thus, the results may not be ideal for the relationship among the variables. Therefore, future researchers should consider the data collection process from a broader and more generalized sample of on-going customers so as to achieve optimum representatives that facilitate decision-making processes by banks' managers in the evaluation of banking website quality.

In the age of the Internet and electronic commerce together with recent changes in external environment of business industry, banks' managers have sought for the innovative and useful service provision initiatives to satisfy customers' continuously changing requirements. One of the most effective ways which have been applied for a long time in Vietnam banking sector is the use of websites to serve customers online. In that aspect the evaluation of customers' perceived website quality remains an urgent need for banks' managers to understand and better serve their customers as well as gain competitive advantages. This suggests an urgent need to search for ways to improve the website quality in an effort to maintain and promote customer satisfaction and loyalty toward the online banking activities in the current information technology context. Furthermore, based on the suggested theoretical model and the results acquired through the regression analysis method, banks' managers are highly recommended to make use of these constructs to identify their effects on customer satisfaction as well as intention to return. The purpose is to develop customer relationship, which can be seen as the core business strategy that determines the success of any service provider in today's competitive market.

\subsection{Managerial implications}

Improving website design and focusing on the interactivity between customers and banks

Customers always associate banking sector websites in online business with a typical shop in traditional business. A beautifully designed shop in which it is also convenient and easy for customers to find goods (or information in online business) will make them satisfied with their transaction behavior. Thus, a website can attract a lot of customers if it possesses a good combination of reasonable layout and harmonious color, as well as ensures its compliance with the guiding principles for bank development. In the process of website design bank managers need to focus on the graphical look of the website, the eclectic mixture of the bank's missions, visions, 
objectives, and the design details and content. At the same time there exists a need to consider the features of website convenience, usefulness, and ease to use so that customers can implement their transactions anytime and anywhere as pointed out by the principles of online business.

In fact, there always exists the situation of "information asymmetry" between the banks and their customers. However, thanks to the delivery of banking service via the Internet, banks can possibly lower its effects by providing sufficient information sources as are required by customers and improving interactivity feature offered by the site.

Improving the security feature, information safety, and customers' trust in the websites

The issue of safety is always one of the barriers to e-business enterprises in Vietnam, in general and in Internet banking in the banking industry sector, in particular. Banks have provided an increasing number of products and services to customers, which leads to the growing risk of information leakage. The transactions conducted on websites are always associated with the circulation of cash flow, so they are actually the target of cyber criminals. Therefore, the careful implementation of safety and security issue aims at ensuring banks' competitive advantages and more importantly, the customers' welfare. Strengthening information security requires coordination and cooperation of people besides efficient technologies and policies, and most of all, it should be a constant process taking place at anytime and anywhere.

The salient fact suggests that we have professional teams working in the field of web design and aesthetics, but the issues of security and information safety on the website are great weaknesses and "obstacles"” for users. Currently, although almost all enterprises require passwords for the login and transaction conducting procedures, the safety/security of online transactions, basically, has not been thoroughly taken into consideration. Therefore, the banks should check for the correctness and authenticity of the transactional information and conduct data storage in different places with many forms. Bank officers need to guide customers through such risk prevention measures as PIN and password to raise their awareness of the security issues. In business, there always exists a great contradiction that, on the one hand, customers want their transactions to be simple and easy-to-use, and on the other hand, they require transactions to meet the security requirements. Thus, it is sufficient for enterprises to 
ensure the security and convenience of customers' transactions at the same time. As a result, banks need to take such initiatives as establishing clear business mechanisms, conducting healthy online sales, focusing on customers' current and potential benefits, and supervise the implementation of customer support policies in order to acquire customers' trust and credibility.

Adjusting the color layout and enhancing both website and information quality

A website which has not been updated with innovative color, technical features, and relevant information for a long time is considered as a "dead" one. Should we not imagine how boring a traditional shop with old paint and disordered shelves become? In online business, in order to develop distinguished websites, banks urgently need to consider changing their colors, updating the new layout (in case these changes do not result in customers' convenience in searching for information on the sites), and constantly bettering the information sources and images reflecting banks' present activities and events. Finally, the enhancement of the credibility of information provided on the websites is also of cardinal importance, apart from the provision of the information that customers actually require

\section{References}

Anderson, E. W., \& Mary, W. S. (1993). The antecedents and consequences of customer satisfaction. Marketing Science, 12(Spring), 125-143.

Anderson, E. W., \& Mittal, V. (2000). Strengthening the satisfaction-profit chain. Journal of Service Research, 3(2), 107-120.

Bagozzi, R. (1992). The self-regulation of attitudes, intentions, and behavior. Social Psychology Quarterly, 55(2), 178-204.

Barnes, S., \& Vidgen, R. (2002). An integrative approach to the assessment of e-commerce quality. Journal of Electronic Commerce Research, 3(3), 114-127.

Barwise, P., \& Farley, J. U. (2005). The state of interactive marketing in seven countries: Interactive marketing comes of age. Journal of Interactive Marketing, 19(3), 67-80.

Bitner, M. J. (1990). Evaluating service encounters: The effects of physical surroundings and employee responses. Journal of Marketing, 54(2), 69-82.

Bowen, J. T., \& Chen, S. (2001). The relationship between customer loyalty and customer satisfaction. International Journal of Contemporary Hospitality Management, 13(5), 213-217.

Brynjolfsson, E., \& Smith, M. D. (2000). Frictionless commerce? A comparison of Internet and conventional retailers. Management Science, 46, 563-585. 
Cai, L., Card, J. A., \& Cole, S. T. (2004). Content delivery performance of world wide websites of US tour operators focusing on destinations in China. Tourism Management, 25(2), 219-227.

Cao, M., Zhang, Q., \& Seydel, J. (2005). B2C e-commerce website quality: An empirical examination. Industrial Management \& Data Systems, 105(5), 645-661. doi: $10.1108 / 17566690911004203$

Castaneda, J. A., Rodriguez, M. A., \& Luque, T. (2009). Attitudes' hierarchy of effects in online user behavior. Online Information Review, 33(1), 7-21.

Chen, J., \& Dibb, S. (2010). Consumer trust in the online retail context: Exploring the antecedents and consequences. Psychology \& Marketing, 27(4), 323-346.

Clyde, M. (2000). Model uncertainty and health effect studies for particulate matter. Environmetrics, 11(6), 745-763.

Cyr, D., Head, M., \& Larios, H. (2010). Colour appeal in website design within and across cultures: A multi-method evaluation. International Journal of Human-Computer Studies, 68(1-2), 1-21.

Devaraj, S., Fan, M., \& Kohli, R. (2002). Antecedents of B2C channel satisfaction and preference: Validating e-commerce metrics. Information Systems Research, 13(3), 316-334.

Eagly, A. H., \& Chaiken, S. (1993). The psychology of attitudes. Fort Worth, TX: Harcourt Brace Jovanovich.

Ehigie, B. O. (2006). Correlates of customer loyalty to their bank: A case study in Nigeria. International Journal of Bank Marketing, 24(7), 494-508.

Gao, X. (2013). The influence of mobile website quality on consumer satisfaction and behavior (MS Thesis). NE: University of Nebraska-Lincoln.

Haque, A., Khatibi, A., \& Al Mahmud, S. (2009). Factors determinate customer shopping behavior through Internet: The Malaysian case. Australian Journal of Basic and Applied Science, 3(4), 3452-3463.

Ho, C., \& Lee, Y. (2007). The development of an e-travel service quality scale. Tourism Management, 28, 1434-1449.

Hoffman, D. L., \& Novak, T. P. (1996). Marketing in hypermedia computer mediated environments: Conceptual foundations. Journal of Marketing, 60, 50-68.

Jalvagi, R. R., \& Moberg, C. R. (1997). Service loyalty: Implications for service providers. Journal of Marketing, 11(3), 165-179.

Kim, H., \& Niehm, L. S. (2003). The impact of website quality on information quality, value, and loyalty intentions in apparel retailing. Journal of Interactive Marketing, 23(3), 221-233.

Kim, S., \& Stoel, L. (2004). Dimensional hierarchy of retail website quality. Information \& Management, 41(5), 619-633.

Kim, S., Shaw, T., \& Schneider, H. (2003). Website design benchmarking within industry groups. Internet Research: Electronic Networking Applications and Policy, 13(1), 17-26. 
Kim, W., \& Lee, H. Y. (2004). Comparison of web service quality between online travel agencies and online travel suppliers. Journal of Travel \& Tourism Marketing, 17(2/3), 105-116.

Kim, W. J., Ma, X., \& Kim, D. J. (2006). Determinants of Chinese hotel customers' e-satisfaction and purchase intentions. Tourism Management, 27(5), 890-900.

Lam, R., \& Burton, S. (2006). SME banking loyalty (and disloyalty): A qualitative study in Hong Kong. International Journal of Bank Marketing, 24(1), 37-52.

Le, V. H., \& Truong, T. T. A. (2012). Research methods in business (in Vietnamese). Hanoi, Vietnam: Finance Publishing House.

Lee, G. G., \& Lin, H. F. (2005). Customer perceptions of E-service quality in online shopping. International Journal of Retail \& Distribution Management, 33(2), 161-176.

Limayem, A., Hillier, M., \& Vogel, D. (2003). Sophistication of online tourism websites in Hong Kong: An exploratory study. In Proceedings of the 2003 Americas Conference on Information Systems (AMCIS, 4-6 August). Tampa, Florida, US.

Liu, C., \& Arnett, K. P. (2000). Exploring the factors associated with website success in the context of electronic commerce. Information and Management, 38(1), 23-33.

Loiacono, E., Watson, R., \& Goodhue, D. (2002). WebQual: A measure of website quality. In K. Evans \& L. Scheer (eds.), Marketing educators' conference: Marketing theory and applications, $13,432-437$.

Luo, X., \& Seyedian, M. (2004). Contextual marketing and customer-orientation strategy for ecommerce: an empirical analysis. International Journal of Electronic Commerce, 8(2), 95-118.

Lymperopoulos, C., Chaniotakis, I. E., \& Soureli, M. (2006). The importance of service quality in bank selection for mortgage loans. Managing Service Quality, 16(4), 365-379.

Madu, C. N., \& Madu, A. A. (2002). Dimensions of e-quality. International Journal of Quality \& Reliability Management, 19(3), 246-258.

McKnight, D. H., \& Chervany, N. L. (2002). What trust means in e-commerce customer relationships: An interdisciplinary conceptual typology. International Journal of Electronic Commerce, 6(2), 35-59.

Mei, C., Qingyu, Z., \& John, S. (2005). B2C e-commerce website quality: An empirical examination. Industrial Management \& Data Systems, 105(5), 645-661.

Miranda, F. J., \& Bañegil, T. M. (2004). Quantitative evaluation of commercial websites: An empirical study of Spanish firms. International Journal of Information Management, 24(4), 313-318.

Miranda, F. J., Cortés, R., \& Barriuso, C. (2006). Quantitative evaluation of e-banking websites: An empirical study of Spanish banks. The Electronic Journal Information Systems Evaluation, 9(2), 73-82. 
Nua Internet Surveys. (2002). Nielsen Netratings: Worldwide Internet populations grows slightly. New York, NY: Nielsen Netratings.

Oliver, R. L. (1999). Whence consumer loyalty? Journal of Marketing, 63(1), 33-44.

Ouellet, J. F. (2008). Brand innovativeness and its effects on consumer responses to brands and innovations (Working Paper). HEC Montreal.

Panda, T. K. (2003). Creating customer lifetime value through effective CRM in financial services industry. Journal of Services Research, 2(2), 157-171.

Parasuraman, A., Berry, L. L., \& Zeithaml, V. A. (1988). SERVQUAL: A multi-item scale for measuring consumer perceptions of the service quality. Journal of Retailing, 64(1), 12-40.

Parasuraman, A., Berry, L. L., \& Zeithaml, V. A. (1991). Refinement and reassessment of the SERVQUAL scale. Journal of Retailing, 67(4), 420-450.

Park, C. H., \& Kim, Y. G. (2003). Identifying key factors affecting consumer purchase behavior in an online shopping context. International Journal of Retail \& Distribution Management, 31(1), $16-29$.

Patterson, M., West, M., Lawthom, R., \& Nickell, S. (1997). Impact of people management practices on business performance. London: Institute of Personnel and Development.

Peterson, R. A., Balasubramanian, S., \& Bonnenberg, B. J. (1997). Exploring the implications of the Internet for consumer marketing. Journal of the Academy of Marketing Science, 25(4), 329-346.

Polites, G. L., Williams, C. K., Karahanna, E., Seligman, L., Elena, K., \& Larry, S. (2012). A theoretical framework for consumer e-satisfaction and site stickiness: An evaluation in the context of online hotel reservations. Journal of Organizational Computing and Electronic Commerce, 22(1), 1-37.

Rafaeli, S. (1988). Interactivity: From new media to communication. In R. P. Hawkins, J. M. Wiemann \& S. Pingree (eds.), Sage annual review of communication research: Advancing communication science: Merging mass and interpersonal processes, 16 (pp. 110-134). Beverly Hills: Sage.

Richard, M. O. (2005). Modeling the impact of internet atmospherics on surfer behavior. Journal of Business Research, 58(12), 1632-1642.

Simon, S. J. (2001). The impact of culture and gender on websites: An empirical study. The Data Base for Advances in Information Systems, 32(1), 18-37.

Smith, B. A., \& Merchant, E. J. (2001). Designing an attractive website: Variables of importance. Proceedings of the 32nd Annual Conference of the Decision Sciences Institute, San Francisco, CA.

Srinivasan, S. S., Anderson, R., \& Ponnavolu, K. (2002). Customer loyalty in e-commerce: An exploration of its antecedents and consequences. Journal of Retailing, 78(1), 41-50. 
Surjadjaja, H., Ghosh, S., \& Antony, J. (2003). Determining and assessing the determinants of eservice operations. Managing Service Quality, 13(1), 39-53.

Syahrul, N. J., \& Sidi, J. (2005). Improving product display of e-commerce website through aesthetics, attractiveness, and interactivity. Proceedings of the 4th International Conference on IT in Asia, CITA 2005, Kuching, Sarawak, Malaysia. 23-27.

Szymanski, D. M., \& Hise, R. T. (2000). E-satisfaction: An initial examination. Journal of retailing, 76(3), 309-322.

Verhagen, T., \& van Dolen, W. (2009). Online purchase intentions: A multi-channel store image perspective. Information \& Management, 46, 77-82.

Weinberg, B. D. (2000). Don't keep your Internet customers waiting too long at the (virtual) front door. Journal of Interactive Marketing, 14(1), 30-39.

Yang, Z., Cai, S., Zhou, Z., \& Zhou, N. (2005). Development and validation of an instrument to measure user perceived service quality of information presenting Web portals. Information \& Management, 42(4), 575-589.

Yoo, B., \& Donthu, N. (2001). Developing a scale to measure perceived quality of an Internet shopping site (SITEQUAL). Quarterly Journal of Electronic Commerce, 2(1), 31-46.

Zhao, M., \& Dholakia, R. R. (2009). A multi-attribute model of website interactivity and customer satisfaction. An application of the Kano model. Journal of Service Theory and Practice, 19(3), 286-307. 